\title{
Racial Residential Segregation and Social Control: A Panel Study of the Variation in Police Strength Across U.S Cities, 1980-2010
}

Stephanie L. Kent

Cleveland State University, s.l.kent59@csuohio.edu

Jason T. Carmichael

McGill University, jason.carmichael@mcgill.ca

Follow this and additional works at: https://engagedscholarship.csuohio.edu/clsoc_crim_facpub

Part of the Criminology Commons, and the Race and Ethnicity Commons

How does access to this work benefit you? Let us know!

\section{Publisher's Statement}

The final publication is available at Springer via http://link.springer.com/article/

$10.1007 \% 2 F s 12103-013-9212-8$

\section{Repository Citation}

Kent, Stephanie L. and Carmichael, Jason T., "Racial Residential Segregation and Social Control: A Panel Study of the Variation in Police Strength Across U.S Cities, 1980-2010" (2014). Sociology \& Criminology Faculty Publications. 112.

https://engagedscholarship.csuohio.edu/clsoc_crim_facpub/112

This Article is brought to you for free and open access by the Sociology \& Criminology Department at EngagedScholarship@CSU. It has been accepted for inclusion in Sociology \& Criminology Faculty Publications by an authorized administrator of EngagedScholarship@CSU. For more information, please contact library.es@csuohio.edu. 


\title{
Racial Residential Segregation and Social Control: A Panel Study of the Variation in Police Strength Across U.S Cities, 1980-2010
}

\author{
Stephanie L. Kent • Jason T. Carmichael
}

\begin{abstract}
Despite a great deal of theoretical and empirical attention given to racial residential segregation and its influence on a number of social problems in the United States, few scholars have examined the role that this persistent form of racial inequality plays in shaping the magnitude of formal social control efforts. Our study examines this relationship by assessing the potential influence that the isolation of minorities may have on efforts to control crime in urban centers across the United States. Using a pooled time-series regression technique well suited for the analysis of aggregate, longitudinal data, we assess the potential influence of racial segregation on the size of municipal police departments in 170 U.S. cities between 1980 and 2010. After accounting for minority group size, economic threat, crime, and disorganization, we find that racial residential segregation has a significant non-linear effect on police force size. Cities with the most racially integrated populations have the smallest police presence but at very high levels of segregation, police strength levels off. This finding is consistent with expectations derived from the contact hypothesis. Under such conditions, majority group members appear to be less inclined to demand greater crime control measures such as increased police protection. Period interactions with residential segregation also suggest that this relationship has grown stronger in each decade since 1980. Overall, our study provides strong support for threat theories and the contact hypothesis but offers necessary refinements.
\end{abstract}

Keywords Police strength $\cdot$ Segregation $\cdot$ Social control

Stephanie L. Kent and Jason T. Carmichael contributed equally to the paper.

\footnotetext{
S. L. Kent $(\bowtie)$

Department of Sociology and Criminology, Cleveland State University, Rhodes Tower 1727, 2121 Euclid Ave., Cleveland, OH 44115, USA

e-mail: s.1.kent59@csuohio.edu

J. T. Carmichael

Department of Sociology, McGill University,

855 Sherbrooke St. West, Rm 713, Montréal, QC H3A 2T7, Canada

e-mail: jason.carmichael@mcgill.ca
} 
Despite efforts to de-segregate racially divided cities during and after the post civil rights era, racial residential segregation remains a pervasive feature of the social landscape in many U.S. cities. The persistent residential segregation of minorities has been linked to a number of social ills. Sociological studies, for instance, have examined the role of segregation in producing higher rates of infant mortality (McFarland \& Smith, 2011), and as a catalyst for the recent foreclosure crisis, whereby cities with high concentrations of minorities were targeted by subprime lenders who marketed risky loans to minority clients (Rugh \& Massey, 2010). A rather small number of important studies have also examined the role that racial residential segregation may play in explaining why and when formal social control mechanisms may be employed. According to these studies, higher levels of residential segregation have been associated with greater arrest rates of African Americans (Liska \& Chamlin, 1984), the size of municipal police departments (Kent \& Jacobs, 2005; Liska, Lawrence \& Sanchirico, 1982), the jail population (Carmichael, 2005), and the prison population (Liska, Lawrence \& Benson, 1981).

Of all aspects related to the criminal justice system, perhaps the most integral element related to the maintenance of social order is police presence. Yet the potential effect of segregation on the size of police forces is largely underexplored. Perhaps this is because nearly all of the prior research on police strength has overwhelmingly attributed changes in police size to the sheer size of racial minority groups, that is, jurisdictions with larger minority populations have the most police. But these studies rarely take into account the geographic distribution of this population across a city and how the residential isolation of minorities may influence how police are used.

While some recent scholarship considered the impact of racial residential segregation on police force size in the United States (e.g. Sever, 2001; Kent \& Jacobs, 2005; Stults \& Baumer, 2007), these studies treat it largely as a control variable in their models. The results from these studies are dated, with only two studies using data from 2000, so they may not reflect current cultural and political conditions in the U.S. Additionally, no prior study has examined the theoretically derived possibility that segregation may have a non-linear association with the size of municipal police departments. If a non-linear relationship does exist between these two factors, results from previous scholarship on police strength would be biased by misspecification. To overcome these limitations, this study will assess theoretical claims regarding the potential non-linear association between racial residential segregation and crime control strategies while simultaneously accounting for several other factors such as crime rates and racial and ethnic composition.

Despite arguments to the contrary, there are reasons to believe that race relations in the United States have not improved enough to eliminate discriminatory practices against minorities. Even the most recent studies of police strength, for instance, overwhelmingly show that a substantial amount of the variation in police force size is explained by the size of the minority population (McCarty, Ren \& Zhao, 2012; Zhao, Ren \& Lovrich, 2012). The theoretical impetus for this relationship comes from the racial threat perspective offered by Blalock (1967) which proposes that as the political or economic threat posed by minority groups grows, dominant group members respond by demanding additional social control resources. While racial and ethnic threat hypotheses enjoy substantial empirical support, if we stop here, we 
risk missing important nuances of racial threat. In particular, it is necessary to consider the well-established association between racial segregation and racial composition (Blauner, 1972). Indeed, in their analysis of segregation in 1981, 1991, and 2001, South, Crowder, and Pais found that whites are more likely to self-segregate in cities with large black populations (2011) suggesting that both the size and distribution of racial minority groups are intrinsically linked in urban society.

Scholarship examining the association between police strength and levels of residential segregation has reported inconsistent findings. Some studies have reported a positive finding while others a negative association between these two factors. Further confusing the situation, different theoretical accounts are offered by scholars to account for their results regardless of the direction they find. One line of thinking is that greater interracial contact in de-segregated cites reduces prejudice and negative stereotypes of minorities among Whites. Alternatively, greater contact between racial groups may emphasize group differences and, thereby, increase racial intolerance tolerance (see DeFina \& Hannon, 2009 for a thorough review of findings that support these two perspectives). In any case, this debate is central to the literature on a variety of social control outcomes, including race disparities in arrest (Ousey \& Lee, 2008), jail admissions (Carmichael, 2005), and the size of municipal police forces (Kent \& Jacobs, 2005; Stults \& Baumer, 2007) because racial threat theory posits that both the size and the spatial distribution of minority groups should influence criminal justice responses that disproportionately target racial and ethnic minorities (Blalock, 1967). Our aim here is to provide some needed theoretical clarity to this debate by testing different specification of this association between racial residential segregation and the size of metropolitan police departments across the United States.

While we focus on residential segregation, we also test alternative hypotheses that explain the variation in the size of local police departments in major U.S. cities over the last several decades. We review these theoretical accounts and their resulting hypotheses in the following section. We then test the strength of these hypotheses using a fixed-effects, pooled time-series analysis of the largest 170 cities in the U.S. between 1980 and 2010. This rigorous methodology allows an investigation of multiple explanations and tests for nonlinear and time-specific interaction effects. The results should help clarify the disparate findings reported in the prior literature and improve our understanding of how race influences levels of social control in modern society.

\section{Theorizing Police Strength}

\section{Racial and Ethnic Threat}

As noted above, studies of police strength overwhelmingly report a strong positive effect of the size of minority populations on the size of municipal police forces. The theoretical justification for this relationship comes from Blalock (1967), who argued that majority groups increase efforts to maintain their social and political dominance as the size of the minority group grows, until it exceeds a certain proportion of the total population. This racial threat theory assumes that citizens and authorities perceive members of racial and ethnic minority groups as a criminal threat to the 
social order (Tittle \& Curran, 1988). This is not surprising given that the literature on racial prejudice supports the proposition that whites who are exposed to blacks are more likely to believe in stereotypes that see blacks as criminal threats. Other sociological studies reveal that whites in cities with more African Americans are more fearful of crime (Liska \& Chamlin, 1984; Quillian \& Pager, 2001). Furthermore, the most racially prejudiced Whites tend to have more punitive attitudes about crime (Cohen, Barkan, \& Halterman, 1991). It follows that majority whites who espouse these views will demand increases in social control, including hiring more police.

Nearly all macro-level studies of police strength support this contention. Jackson (1989), and Nalla, Lynch, and Leiber (1997) show that minority group threat leads to increased expenditures on police while other research reports the same effect on the number of police officers per capita (Jacobs, 1979; Liska et al., 1981; Sever, 2001; Sharp, 2006; Kent \& Jacobs, 2005; Holmes, Smith, Freng \& Munoz, 2008; McCarty et al., 2012; Zhao et al., 2012). These studies show that when blacks make up a large proportion of the population, control efforts are strengthened regardless of the crime rate, suggesting that cities with a larger percentage of African Americans will have more police.

Some of the above studies further investigate this relationship by testing whether the relationship between the size of the Black population and levels of social control is non-linear. Jackson and Carroll (1981) reported a curvilinear effect of the percent black on government spending on the police, and Kent and Jacobs (2005) and Stucky (2005) found this effect on police force size suggesting that the "threat" felt by whites is highest in places with a moderate minority population, but less apparent in communities with low or very high proportions of racial or ethnic minorities. Sever (2001) found that percent black was non-significant in a subsample of cities that had less than $30 \%$. Stults and Baumer (2007) found a curvilinear effect of the percentage Black on police force size with a tipping point around $30 \%$. Some of these scholars argue that as minority populations grow, they gain the political power necessary to counter attempts to use city level politics to respond to perceived racial threat. Based on these findings and the compelling theoretical assumption, we predict that the number of police will expand as African-Americans comprise a higher proportion of a city's general population but may have trivial effects once a threshold has been reached.

But other minority groups may also influence the size of municipal police departments. Dating back to Jackson (1989), who reported a significant relationship between the percentage of Hispanics and police expenditure in cities, a handful of studies of police strength tested an ethnic version of racial threat operationalized by the percentage of Hispanics. This relationship is plausible since in some cities, Hispanics occupy the largest minority group. According to threat theories, whites should also respond to perceived threat posed by this group by demanding additional social control.

The results of studies that tested this assumption, however, have been mixed. Both Stucky (2005) and Kent and Jacobs (2005), for example, found positive effects of the percentage of Hispanics on police strength in cities while Zhao et al. (2012) found a negative effect and Sever (2001) no effect. Analyzing only cities in the Southwestern U.S., Holmes et al.'s, 2008 study of police strength did reveal a positive but 
surprisingly small effect. In fact, Holmes et al. (2008) and Kent and Jacobs (2005) reported that the effect of racial (African-American) threat was much more pronounced than the ethnic threat posed by Hispanics. But all of these studies are now dated and do not capture the recent growth in the Hispanic population. Since no study has yet tested this version of the theory using 2010 data, and given the substantial increases in the Hispanic population in the U.S. in recent years, we hypothesize that cities with a larger percentage of Hispanics will have more police.

\section{Racial Residential Segregation}

The above explanation focuses on the relative size of racial or ethnic minority groups, but the physical distribution of minority groups within a city should also affect the allocation of policing resources. An examination of segregation is a logical extension of and complement to the above version of racial threat when we consider the effect segregation has on interracial contact. Allport's (1954) classic contact hypothesis suggests that racial integration reduces inter-group hostility and prejudice. Thus, when Whites and African-Americans have more contact as a result of residential integration, whites are less likely to hold negative perceptions of racial minorities. A substantial body of literature now supports this claim. For instance, Welch, Sigelman, Bledsoe and Combs (2001), in their longitudinal study of Detroit, found that residential integration promotes interracial contact and reduces interracial hostility suggesting that negative attitudes can be attenuated through increased exposure to different types of communities. Whites who live in highly segregated neighborhoods and are only exposed to racial minorities through the mass media are likely to hold erroneous stereotypes (Dyer, Vedlitz, \& Worchel 1989; Lee 2000; Hum \& Zonta, 2000).

Applied to racial threat theory, the increased interracial contact provided by reduced residential segregation should diminish perceived threat posed by minority groups. It stands to reason that a reduction in whites' fear of unfamiliar racial groups would decrease their demands for increased social control efforts that largely target minorities. Put differently, in the most segregated places in which whites and racial minorities rarely interact, white fear and the resulting punitive responses to perceived threat should be greatest because the interpersonal interracial relationships that may have dispelled these stereotypes are reduced.

Recent scholarship suggests that police administrators do, in fact, respond to highly segregated and concentrated areas of racial minorities by hiring additional police (Stults \& Baumer, 2007; Sever, 2001). Sever's (2001) study of municipal police departments showed that black-white segregation had a positive effect on the number of sworn officers in 1980 but not on expenditures on the police. He contended that police administrators are threatened by the presence or increase of highly segregated African-American neighborhoods, and, given the substantial influence they have on decisions about funding allocation for additional hires, will respond by adding more police. Therefore it is plausible that it is the concentration of racial minorities, rather than only changes in the mere presence of this racial group, that leads to increases in police strength.

While most of the studies discussed above suggest a linear relationship between residential segregation and the size of the police department, this relationship may be 
more complex. It is plausible that the direction of the effect of segregation depends on the overall level of segregation. Just as the size of the minority population has a "tipping point" in which racial threat is attenuated once the minority population exceeds a certain percentage of the population, perhaps segregation has a similar effect. Specifically, it seems plausible that cities would add police in response to the threat posed by a segregated minority, but after a certain threshold is reached, the perceived danger of this group becomes less apparent because they are so distant and isolated. There are theoretical accounts to support such a claim. Wacquant (2001) proposes that both criminal justice mechanisms and the isolation of AfricanAmericans in urban ghettos serve as social controls that maintain racial discrimination. Blalock (1967), for instance, proposed that extreme levels of racial residential segregation serve as a buffer that attenuates the threat perceived by whites because contact between races is minimized. Restrictive residential arraignments may limit the amount of contact between Whites and minorities (even if the minority population is large) because segregation geographically isolates minorities into urban ghettos far from most Whites. This residential isolation should, in turn, diminsh white perception of the risk of interracial victimization and thereby reduce dominant group fear of crime. In other words, racial residential segregation largely eliminates the need for aggressive social control because dominant group fears about interracial crime are reduced without the need for alternative measures of social control (Blauner, 1972; Spitzer, 1975; South \& Felson, 1990). If that is the case, places with the highest levels of segregation should have less need for larger police departments.

There are other theoretically derived reasons to believe that very high levels of residential segregation will lead to a reduction in police force size. The "benign neglect" hypothesis, for instance, proposes that law enforcement agencies police neighborhoods with high concentrations of racial minorities less aggressively because police are more responsive to interracial crime and less likely to respond to the intraracial crime most likely found in these communities (Liska et al., 1981). More recently, Myer and Chamlin, (2011) explored this theory at the police district level in one large city, and reported evidence of benign neglect in the most economically disadvantaged minority neighborhood. Additional empirical research supports a negative relationship between segregation and social control mechanisms in the criminal justice system. Kent and Jacobs (2005) found fewer police officers in cities in which a substantial black population is residentially isolated from areas where whites reside.

In sum, the above discussion suggests that the relationship between residential segregation may be non-linear. Following the contact hypothesis, cities with the most integrated populations should have the fewest police officers. According to the threat hypothesis, as minorities become more isolated, prejudice and negative stereotypes flourish. Subsequently, dominant group fears of minorities grow, and greater demands for formal social control presumably follow. However, Blalock's version of the threat hypothesis predicts that the effect of racial threat should subside once some high threshold in residential segregation has been reached. We therefore propose that segregated cities should have more police, but at extreme levels of segregation, there will be a reduction in police strength. Support for this model would be found if the squared term yields a significantly negative coefficient, while the non-squared term is significantly positive. 
Finally, segregation in urban areas is a dynamic process. Indeed, there is considerable literature devoted to measuring and explaining changes in residential segregation over time in the United States. From 1980 to 2010 (the period examined here), whites in metropolitan areas are more likely to be exposed to nonwhites, though the opposite trend has been observed for African-Americans (South et al., 2011). Therefore, we consider the possibility that any effect of segregation on police strength may not be stable over time.

\section{Economic Threat}

While most of the police strength literature focuses on racial threat, an economic threat explanation may be just as plausible. Stemming from conflict theories of social order, social control mechanisms in an unequal society such as the United States may be used in a discriminatory way that serves to reproduce and maintain a socioeconomic structure that favors the affluent at the expense of the poor. This perspective complements the racial threat theory because race and class are so synonymous in urban areas in the United States. That is, perhaps it is classism that drives changes in police strength rather than (or in addition to) racist attitudes. Oliver and Mendelberg (2000) support this contention in their study of racial attitudes in which they found that differences in white racial antagonism across the South were not simply due to the size of the African-American population, but shaped more by whites' perception of interracial economic competition. If this is true, then demands for stronger police may stem from responses to the economic context in urban places.

This contention aligns with conflict theories that equate political power with wealth in modern society. A concentration of income gives elites greater control over political decision-making including those related to the social control (Chambliss, 1976), and when inequality is high, the rich enjoy the benefit of increased political power relative to the poor (Jacobs \& Helms, 1997). These theories would suggest that such an unequal social arrangement cannot be maintained without a social control apparatus that favors the rich at the expense of the poor. The affluent, therefore, should use their political power to maintain their social position. One way this can be achieved is by promoting social control functions that control the poor. The police, who typically focus on public street crime in poor neighborhoods (Rubenstein, 1973; Wilson, 1971), serve to accomplish this function. And the rich have an additional reason to demand a strong police force. Fear of street crime (independent of the likelihood of actual victimization) may contribute to their desire to maintain or increase the size of the police.

Some empirical studies on police strength have tested whether economic stratification is an important determinant of police size and results vary, probably because these studies used a variety of measures of economic inequality. For example, McCarty et al. (2012) used unemployment and per capita income to measure economic inequality and found that the former was not a significant predictor of police strength in U.S. cities but the latter had a negative effect. Zhao et al. (2012) also assessed inequality using unemployment rates and found similarly surprising negative effects on the rate of police employees. Holmes et al. (2008) used a race-based measure of inequality and found that Southwestern cities with a larger gap between Hispanic and white median income had higher levels of police strength, though they 
found no effect of the African-American to white median income. Finally, Stucky (2005), and Stults and Baumer (2007) used the Gini index of income inequality to predict police strength. The former found an implausible negative effect on police strength in large U.S. cities while the latter found no effect. Despite the variation in findings, based on theoretical expectations, and because so many studies highlights the role of inequality regardless of its specification, we include it in our analysis with the expectation that: As the overall economic inequality of a city increases, police size will increase.

\section{Additional Factors}

Crime and Social Disorganization While the size of police forces should depend partly on the amount of crime, the empirical research supporting this association is quite mixed. Some find no evidence for a relationship between crime rates and police strength (Loftin \& McDowall, 1982; Kent \& Jacobs, 2005; McCarty et al., 2012) but a few do support this link (Bordua \& Haurek 1971; Gurr, 1979; Liska et al., 1981; Jacobs \& Helms, 1997). These inconsistencies are largely due to variations in the measure of crime, time periods and units of analysis, however, theory and convention suggest that this relationship is important so we include serious crime rates in all of our analyses and predict that cities with higher crime rates will have larger police departments.

While a link between officially-reported crime rates and police strength is plausible, police administrators and the public may perceive an increased need for law enforcement in socially disorganized places. Police must attend to issues related to general social disorder that are common in disadvantaged urban communities. But these calls for service, responses to unsupervised juveniles, and other common policing activities are not captured by official crime statistics. Prior studies have included a variety of control measures to account for this unmeasured disorder. We employ the percentage of female-headed households and predict that cities with a high proportion of female headed households will have more police.

Other Controls We include three additional controls that have been shown to contribute to police strength. First, large police forces require ample finances (Stucky, 2005; Holmes et al., 2008; McCarty et al., 2012; Zhao et al., 2012). Kent and Jacobs (2005) suggest that a city's tax base is a good indication of available funding for law enforcement agencies which may translate into more police. Second, maintaining order is more difficult in places with large populations (Hahn, 1971) so larger communities should require more police per capita (Bordua \& Haurek, 1971, Maguire, 2001).

Finally, some of the literature on social control agencies has established a link between high unemployment rates and greater levels of social control (c.f. Sutton, 2000; Chiricos \& Delone, 1992) based on the neo-Marxist claim that social control mechanisms such as imprisonment are used to control a surplus of labor in capitalist economies (Rusche \& Kirchheimer, 1939). This finding is consistent with the economic threat argument that more police are necessary to control a potential criminal threat posed by the unemployed. Recent studies on police strength have produced mixed findings with some finding a positive effect of unemployment (Kent \& Jacobs, 
2005), others finding no effect (McCarty et al., 2012) and one finding a negative effect (Zhao et al., 2012). Consistent with the predicted effect of enhanced economic inequality, we expect that cities with high unemployment may have larger police forces.

\section{Methodology}

The Sample and Dependent Variable

To test the hypotheses outlined above, we compiled a time-series dataset to include decennial census data on 170 cities in the United States between 1980 and 2010. The 170 cities in our sample are those with over 100,000 residents as recorded in the 1980 census. We employ this particular sampling strategy for two reasons. First, to maintain consistency across each panel we chose a population threshold defined in our first panel. Without doing so, our analyses would be complicated by a different sample size for each panel. We use a population of 100,000 residents as the lowerlimit of our sample because we are particularly interested in how major urban cities in the country employ social control in response to our theoretically derived set of factors. We assume different mechanisms are a play in smaller communities. While previous studies of police strength have varied in the population threshold used to capture urban centers, most have used cities with over 100,000 residents as their sample. To remain consistent with the relevant studies, then, we use the same population size for our sample of cities. Due to missing data for some of our variables, our sample drops to 564 city-years for all of our multivariate regression analyses.

We confine our analysis to decennial census years because it has some important advantages over, say, an annual series. First, most variables of interest in our study are unavailable in off-census years. Some form of interpolation could fill-in gaps in our data but even the most sophisticated techniques introduce measurement error thereby degrading our estimates. To avoid this outcome, we limit our analysis to census years. Long gaps between panels have other advantages. Perhaps most importantly, space between periods in a panel analysis can substantially reduce the risk of serial correlation (see Johnston \& Dinardo, 1997) which can bias coefficients. Finally, existing research on police strength has largely been confined to census years (e.g. Greenberg \& West, 2006; Jacobs \& Carmichael, 2001; Kent \& Jacobs, 2005). Thus, comparisons with findings from these studies are more appropriate. Given these advantages, our findings will be comparable to other studies and produce the most reliable estimates of the variation in police strength.

The dependent variable is the rate of sworn police officers per 100,000 residents. This operationalization of police strength is consistent with most other studies in the relevant literature (e.g. McCarty et al., 2012; Holmes et al. (2008); Kent \& Jacobs, 2005; Nalla et al., 1997). Measuring police strength as a rate instead of raw numbers is the preferred measure because it automatically accounts for the vast differences in population across cities in our sample. Data for the dependent variable is taken from the Police Employee data (LEOKA) contained in the Uniform Crime Reports (UCR). 
We run all of our regression models using a fixed-effects pooled time-series estimation technique. Pooled time-series is preferred over a simple cross-sectional study because it can capture both cross-sectional and longitudinal variation in police strength. Using fixe-effects adds additional advantages over random-effects. The principle strength of fixed-effects is that it automatically controls for all timeinvariant city-level factors that are not included in the model. Thus, fixed-effects allows us to make greater claims that factors not included in our analysis such as cultural differences, political arraignments or police culture are taken into account and therefore not biasing our results. Given this substantial advantage fixed-effects has over random-effects, recent studies on police strength have all used fixed-effects (McCarty et al., 2012; Zhao et al., 2012; Kent \& Jacobs, 2005). But fixed-effects models are not always appropriate unless tests suggest it produces the most consistent estimates. In our case, the Hausman test suggests that fixed-effects is preferred and will produce the most reliable results (see Greene, 2012 for elaboration). Findings from this test suggest that the error term for each city is not correlated with other cities. Thus, each city contains unique characteristics that may influence the outcome. Fixed-effects models can account for these unobserved differences but random-effects cannot.

Our modeling strategy also includes an assessment of the shifts in police strength over time as well as an examination of the strength of specific relationship across time-periods. To accomplish this, all of our models include a set of dummy variables to account for each decennial census panel. In some models, we also include an interaction term between time and residential segregation. By using period interactions, we can ascertain how the influence of residential segregation may have changed over the last several decades. Finally, we include a correction for unspecified heteroskedasticity in all of our models to ensure our models are robust and consistent in the face of potential problems with the error variance.

\section{Measurement}

Data for the explanatory variables was largely taken from each decennial census from 1980 to 2010 . We gauge the extent of residential segregation in each city with the index of dissimilarity. This commonly used measure of residential segregation indicates the odds that an African American will come into contact with a White person by taking into account the geographic concentration of each group within census blocks. The index ranges from zero (no racial residential segregation-i.e. all blocks have same racial composition as the entire city) to 100 (complete residential segregation-i.e. no census block has mixed racial composition). A number of alternative measures of segregation exist but the index we use is the most often used in criminal justice research so using the index of dissimilarity will make our results more comparable to other studies (see Messner \& Golden, 1992 for a detailed discussion of the advantages and disadvantages of our measure of segregation as well as alternative measures). We include a squared term of segregation in some models to test hypotheses derived from contact hypothesis which suggest that relationship between segregation and police strength may be non-linear. 
We measure racial threat as the percentage of African Americans in each city. Ethnic threat is operationalized with the percentage Hispanic. In some models, we also introduce a squared term for each of these threat variables to see if more political versions of the threat hypothesis apply to police strength. An economic version of the threat hypothesis is assessed using a pair of indicator. Unfortunately, there has been a great deal of inconsistency in the measurement of income inequality in the extent literature. Scholars have used any number of measures to assess the level of economic stratification within a society including unemployment rates, poverty rates, income differences by racial group, but the most conventional measure has been the Gini index (for a detailed discussion of the index see Land, McCall, \& Cohen, 1990; Kelly, 2000; Pratt \& Cullen, 2005). The advantage of the Gini index is that it is widely available, uncomplicated to calculate and interpretation is straightforward. Additionally, one of the few studies to test the influence of income inequality on police strength (Stucky, 2005) used the Gini index as the measure so the results from our studies should be easily comparable. The Gini index ranges from zero (perfect equality-i.e. income is spread equally across all individuals) to 1.0 (perfect inequality-i.e. one household holds all the income). The extent of unemployment is an alternative measure on economic threat. To account for the possibility that this is a better means of capturing economic stratification we include the unemployment rates in all of our models. We log the unemployment rate in all of our models to correct for skewness.

We use several measures to operationalize differences in crime across the cities in our sample. In some of our models we assess crime use the rate of serious crime. Serious crime rates include both violent and property crime. To see if these types of crime operate differently on police strength, we separate these crime rates in some models. While flawed, these crime figures receive much media attention so the public and city politicians would likely take their cues from these statistics if they thought more police were needed. Each of these measures is taken from the FBI's Uniform Crime Reports.

Finally, to be consistent with prior studies on police strength (Kent \& Jacobs, 2005) we account for differences in each city's fiscal capacity to spend on policing using median household income. Household income acts as a proxy for the tax base of the city. While alternative measures exist such as tax revenue or spending on police, these factors may be manipulated at any time by local politicians. Using household income as the proxy for resource differences is a better reflection of base resource capacities available to each city. To assess social disorganization we include the percentage divorced in some of our models.

\section{Results}

\section{Descriptive Statistics}

Table 1 presents the predicted directions, means, standard deviations, and ranges for all of the variables in our analyses. These summary statistics evince the substantial variation in the rate of police strength across space and time. While the average city in our sample has 220 officers for every 100,000 residents, the rate of police presence is 
as low as 85 in Sunnyvale California and as high as 806 in Washington, DC. Sizable but less dramatic shifts have also taken place over time. In 1980 the average city police department had 205 officers per 100,000 residents. This figure has increased to a rate of 240 officers. The principle purpose of this study is to understand why such vast differences exist in cities across the United States.

Other summary statistics are also worth discussing. Of particular interest are the descriptive for residential segregation. We see that the average degree of racial residential segregation across the 170 cities in our sample is 59.85. Conceptually, the figure represents the percentage of African Americans who would have to change their residence to a predominantly White neighborhood in order to achieve a racial distribution similar to the city as a whole (see Massey \& Denton 1989 for discussion). In other words, nearly $60 \%$ of African Americans in each of the 170 cities would have to move to a predominately White neighborhood to achieve racial integration. But residential segregation varies substantially across our sample from a low of 19.89 in Eugene, Oregon to a staggering high of 92.8 in Livonia, Michigan located just outside of Detroit.

Finally, the descriptive statistics identify substantial differences in minority presence across cities. It is clear from these statistics that both African Americans and Hispanics are geographically concentrated into specific cities in the United States and are nearly absent from others. In Livonia, Michigan the percentage African American is less than one. This should not be surprising given the discussion on residential segregation outlined above. Conversely, in Gary Indiana the African American population is $84 \%$ of the overall population. The Hispanic population is similarly concentrated into certain urban centers in the United States. Over $90 \%$ of the population in Hialeah, Florida, for instance, is Hispanic. Yet, some cities are nearly devoid of Hispanics (e.g. less than one percent in Jackson Mississippi). Beyond the geographic concentration of minorities, perhaps even more interesting is the growth in this population across major U.S. cities. While the African American population in our sample of cities grew from $19.1 \%$ in 1980 to over $25 \%$ in 2010 , the Hispanic population exploded from $9.1 \%$ to $21.6 \%$ during the same time period (representing

Table 1 Means and standard deviations over time and across cities ( $n=564$ City-years)

\begin{tabular}{llllll}
\hline Variable & Predicted direction & Mean & SD & Min & Max \\
\hline Sworn police per 100,000 & & 220.53 & 87.73 & 85.35 & 805.57 \\
Residential segregation & NL & 59.85 & 15.83 & 19.89 & 92.8 \\
\% Black & NL & 20.50 & 17.49 & .08 & 84.03 \\
\% Hispanic & NL & 14.55 & 16.66 & .37 & 94.7 \\
Serious crime rate & + & 7714.60 & 3123.8 & 1825.13 & 19235.97 \\
Violent crime rate & + & 957.48 & 646.2 & 126.05 & 4353 \\
Property crime rate & + & 6776.23 & 2751.4 & 1430.54 & 23517.98 \\
Income inequality (GINI) & + & .44 & .05 & .28 & .63 \\
Logged unemployment rate & + & 1.86 & .52 & .26 & 2.99 \\
Median family income & + & 37,401 & 16,941 & 11989 & 102943 \\
\% Female headed families & + & 26.01 & 10.38 & .02 & 53.18 \\
\hline
\end{tabular}


a $233 \%$ increase). Our multivariate analyses will allow us to see if these changes in the racial and ethnic composition have influenced the size of municipal police departments across the United States.

\section{Multivariate Results}

Results from our pooled time-series analysis are presented in Table 2. Our first model presents the findings from a smaller set of variables. This model does not include the non-linear specification of our racial and ethnic threat variable and ignores any of the period interaction terms. Model 2 considers the possibility that residential segregation as well both threat variables have a non-linear relationship with police strength. The third model examines an alternative specification for crime by examining property and violent crime rates separately rather than the combined crime rates estimated in the previous two models. The third model also introduces the remaining control for family instability (the percentage of households that are female-headed). Our final model removed the squared term for residential segregation so we can appropriately assess interaction terms between each period and segregation.

Findings from Model 1 show that, despite conventional wisdom, the rate of serious crime does not influence police strength across large U.S. cities. If differences in crime rates are not responsible for differences in the size of municipal police departments, what factors are? Our initial model provides some answers to this question. It appears that the most residentially segregated cites and those with the most Blacks have higher rates of police strength but, despite our predictions, Hispanic presence does not reach significance in this early model. Additionally, differences in economic inequality also appear to be playing a strong role in determining the size of local police departments. Together, these results point to a link between police strength and specific contextual factors such as a city's racial composition, the extent to which racial minorities are residentially isolated, and the degree of income inequality within those cities. But theory suggests the relationship between several of our contextual variables may not be linear. Model 2 tests these assumptions.

The results from Model 2 support our expectation about the non-linearity of several key variables. First, we see that the relationship between racial residential segregation and the size of police forces is non-linear such that it takes the shape of an inverted U. Consistent with our hypotheses, it appears that as African Americans become more segregated into specific neighborhoods within a city there are increases in the size of municipal police departments but this rate of increase diminishes at higher levels of segregation. We will discuss this relationship in more detail below. A city's racial and ethnic compositions are also associated with police force size in a non-linear fashion. As expected from the more political version of threat hypotheses, cities with a larger African American presence have a greater police presence but the effect diminishes, leveling off at higher proportions of racial minorities. Aside from these findings, we see that income inequality is an important predictor of police strength but the serious crime rate does not account for shifts in our outcome.

It could be that local politicians respond to different types of crimes when considering police force size. We examine this possibility along with another control variable that considers the influence of social disorganization on police strength. Model 3 separates the serious crime rates into its two principal 
Table 2 Fixed-effects, pooled time-series regression estimates of the rate of sworn police officers in large U.S. cities (1980-2010)

\begin{tabular}{|c|c|c|c|c|}
\hline & Model 1 & Model 2 & Model 3 & Model 4 \\
\hline \multicolumn{5}{|l|}{ Residential segregation } \\
\hline \multirow[t]{2}{*}{ Segregation } & $.700 * *$ & $1.938 * *$ & $1.921 * *$ & .351 \\
\hline & $(.283)$ & $(.703)$ & $(.685)$ & $(.323)$ \\
\hline \multirow[t]{2}{*}{ Segregation Squared } & - & $-.011 *$ & $-.011 *$ & - \\
\hline & & $(.006)$ & $(.006)$ & \\
\hline \multicolumn{5}{|l|}{ Racial/Economic threat variables } \\
\hline \multirow[t]{2}{*}{$\%$ Black } & $3.644 * * *$ & $5.127 * * *$ & $5.801 * * *$ & $5.842 * * *$ \\
\hline & $(.739)$ & $(1.185)$ & $(1.263)$ & $(1.169)$ \\
\hline \multirow[t]{2}{*}{$\%$ Black squared } & - & $-.023 *$ & $-.033 * *$ & $-.035 * *$ \\
\hline & & $(.013)$ & $(.013)$ & $(.013)$ \\
\hline \multirow[t]{2}{*}{$\%$ Hispanic } & -.312 & $-1.458 *$ & $-1.086^{*}$ & $-1.121 *$ \\
\hline & $(.296)$ & $(.724)$ & $(.599)$ & $(.597)$ \\
\hline \multirow[t]{2}{*}{$\%$ Hispanic squared } & - & $.016^{*}$ & $.013^{*}$ & $.015^{*}$ \\
\hline & & $(.009)$ & $(.007)$ & $(.008)$ \\
\hline \multirow[t]{2}{*}{ Gini index } & $185.263 *$ & $188.959 *$ & $154.180^{*}$ & $151.278+$ \\
\hline & $(90.469)$ & $(92.793)$ & $(92.551)$ & $(95.508)$ \\
\hline \multirow[t]{2}{*}{ Logged unemployment rate } & .486 & 1.014 & -1.089 & .026 \\
\hline & $(5.232)$ & $(5.227)$ & $(5.573)$ & $(5.528)$ \\
\hline \multicolumn{5}{|c|}{ Year dummies (1980 is omitted category) } \\
\hline \multirow[t]{2}{*}{$1=1990$} & 8.388 & 5.185 & 19.150 & 12.936 \\
\hline & $(9.646)$ & $(9.611)$ & $(11.543)$ & $(22.942)$ \\
\hline \multirow[t]{2}{*}{$1=2000$} & $23.378+$ & 20.943 & $28.979 *$ & -6.116 \\
\hline & $(13.493)$ & $(13.418)$ & $(13.795)$ & $(25.137)$ \\
\hline \multirow[t]{2}{*}{$1=2010$} & 14.390 & 11.015 & 27.504 & -31.972 \\
\hline & $(17.871)$ & $(17.215)$ & $(19.071)$ & $(27.311)$ \\
\hline \multicolumn{5}{|l|}{ Control variables } \\
\hline \multirow[t]{2}{*}{ Serious crime rate } & .002 & .001 & - & - \\
\hline & $(.001)$ & $(.001)$ & & \\
\hline \multirow[t]{2}{*}{ Violent crime rate } & - & - & -.011 & -.007 \\
\hline & & & $(.007)$ & $(.007)$ \\
\hline \multirow[t]{2}{*}{ Property crime rate } & - & - & $.004 *$ & $.004 *$ \\
\hline & & & $(.002)$ & $(.002)$ \\
\hline \multirow[t]{2}{*}{ Median income } & .000 & .000 & $.001 *$ & $.001 * *$ \\
\hline & $(.000)$ & $(.000)$ & $(.000)$ & $(.000)$ \\
\hline \multirow[t]{2}{*}{$\%$ Female headed households } & - & - & $.915 * *$ & $1.056 * * *$ \\
\hline & & & $(.334)$ & $(.332)$ \\
\hline \multicolumn{5}{|l|}{ Interaction terms } \\
\hline \multirow[t]{2}{*}{ Segregation*1990 } & - & - & - & .032 \\
\hline & & & & $(.318)$ \\
\hline \multirow[t]{2}{*}{ Segregation*2000 } & - & - & - & $.515^{*}$ \\
\hline & & & & $(.289)$ \\
\hline
\end{tabular}


Table 2 (continued)

\begin{tabular}{lllll}
\hline & Model 1 & Model 2 & Model 3 & Model 4 \\
\hline Segregation*2010 & - & - & - & $1.008^{* * *}$ \\
& & & & $(.311)$ \\
Constant & -3.881 & -45.270 & -84.061 & -40.063 \\
\# of City-Years & 564 & 564 & 564 & 564 \\
Adj. $\mathrm{R}^{2}$ & .902 & .903 & .907 & .909 \\
\hline
\end{tabular}

$+P \leq .1 ; * P \leq .05 ; * * P \leq .01 ; * * * P \leq .001$. One-tailed tests on all coefficients except the decade dummies and the unemployment rate. Robust (corrected for heteroskedasticity) Standard Errors are in parentheses. All models corrected for unspecified heteroskedasticity using White's (1980) correction

components - violent crime and property crime. With these rates separated, we find some support for the conventional explanation associated with the variation in police strength. Specifically, we see that violent crime rates are not significantly related to our outcome but property crime rates do have a positive and significant effect. It is plausible that city managers respond to shifts in property crimes because the vast majority of overall crime is property crime. In addition to the significant effect of property crime, Model 3 also shows that the hypothesis derived from social disorganization theory is also supported. Our measure of family disruption is a positive and significant predictor of police strength. It is noteworthy that the variables included in Model 3 account for over $90 \%$ of the variation in the variation in the size of municipal police departments across the United States. Before we summarize our findings, though, we will elaborate on our results related to residential segregation.

\section{A Closer Look at Residential Segregation}

Our second and third models show that the relationship between racial residential segregation and the size of local police departments is non-linear in the shape of an inverted U. To illustrate this relationship, Fig. 1 plots the association between segregation and the outcome. From this depiction, we see that the rate of police strength is the lowest in the most integrated cities. This is consistent with expectations derived from the contact hypothesis. However, as racial threat theory would predict when racial minorities become more segregated into isolated neighborhoods we see a rise in police strength. According to threat hypotheses, this increase in social control is a function of an increase in fears toward minorities. Though in our sample, very few cities have extreme levels of segregation, the figure illustrates that at the highest levels of segregation, police strength begins to diminish, because, perhaps as Blalock (1967) surmised, segregation serves to isolate African-Americans from whites, reducing interracial contact and perceived threat.

But because our series covers several decades and major societal shift have taken place during this period, a number of contextual and cultural factors may have changed with regards to their influence on the size of municipal police departments. In particular, some scholars have suggested that race relations in the United States are declining in their significance (e.g. Wilson, 1978). If this is the case, we should 


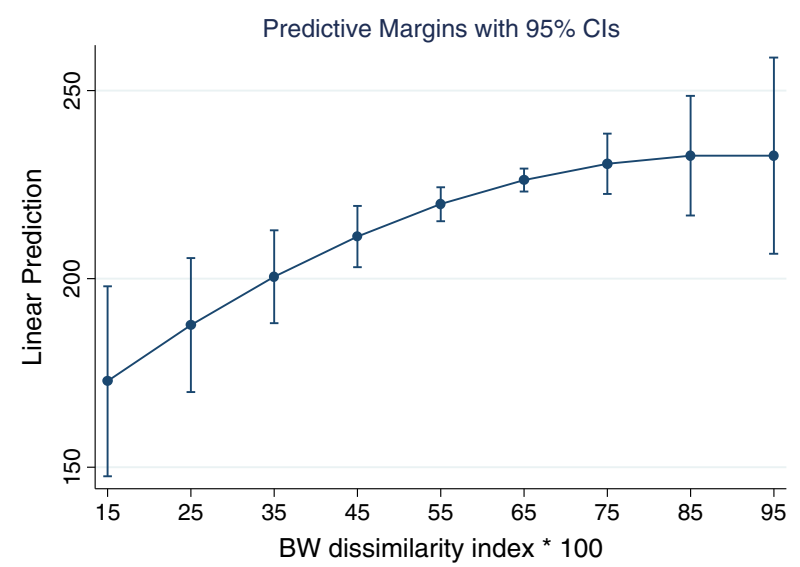

Fig. 1 Plot of the relationship between segregation and police strength

expect to see factors related to race have a diminishing influence on social control outcomes. To test this possibility our final model in Table 2 examines a set of interaction terms between the level of racial residential segregation and the period dummies. Despite predictions to the contrary, the results from Model 4 indicate that the influence of racial segregation on police strength has increased in each decade since 1980. This finding suggests that levels of racial segregation not only continue to play a substantial role in determining the size of local police departments, the influence of the isolation of minorities on police strength is on the rise.

\section{Conclusion}

Findings

A rather significant body of literature which examines the variation in the size of local police departments has accumulated over the last few decades (see Sever, 2001 for a review of many of these studies). Yet, given the scholarly interest in this topic, it is surprising that no previous study has paid significant attention to the potentially significant role that racial segregation may have on variations in police strength. The goal of this study has been to fill this void in the extant literature. The analysis not only examines differences in police strength across a large sample of the largest 170 cities in the United States, it also explores factors that have led to changes in rates of police presence over the last several decades. Our results provide consistent evidence that after controlling for differences in crime rates and population size, several contextual factors have contributed to the size of municipal police departments.

A few of our results are particularly noteworthy as they provide important insight into the variations in police strength across large U.S. cities. Perhaps our most novel finding is the relationship between racial residential inequality and our outcome measure. After testing both the linear and non-linear specification, our analyses suggest that the relationship is best understood as curvilinear. As Fig. 1 shows, the most integrated cities have smaller police departments per 100,000 residents. This is consistent with the contact hypothesis which suggests that hostile attitudes should 
decline when members of different ethnic groups live in the same neighborhood. This is believed to be the case because negative stereotypes are reduced when equal-status contact occurs between different racial or ethnic groups (see Ellison \&Powers 1994 for elaboration). Scholars suggest that contact between different groups exposes them to the similarities in their attitudes, behaviors and in doing so decreases traditional stereotypes. So, to the extent that majority group members are threatened by a large minority population, this fear appears to reduce with contact.

Yet, we see from our results that once interracial contact begins to decline, threat associated with minority groups appears to rise (as evinced by greater levels of social control). This increase is consistent with the expectations of both traditional threat theories as well as the contact hypothesis. At the highest level of segregation, Fig. 1 shows that there is a diminishing effect associated with segregation. It seems plausible that majority group members are less threatened in cities where Blacks are the most residentially isolated. Under these conditions, residential segregation may make formal control efforts less necessary because the risk of interracial crime drops substantially. Furthermore, the examination of interactions between segregation and the decade dummies show that the strength of this association has only increased over time despite the substantial strides made in race relations in the United States.

In addition to our findings associated with residential segregation, our results also point to other important contextual factors related to police strength. In particular, social threat explanations received great support from in our analyses. Consistent with most previous studies, racial and ethnic threat are each consistent, robust predictors of the size of municipal police departments (e.g. Stucky, 2005; Jacobs \& Kent, 2005; see Sever, 2001 for a review). Our findings are somewhat novel, though, as we test and find support for a non-linear relationship between the threat measures and police strength. Most studies only consider a direct relationship (see Stucky, 2005 and Sever, 2001 for exceptions) but both theory (Blalock 1967) and empirical evidence (Jackson, 1989) suggests that these relationships are non-linear. Results suggest that as African American presence grows there is a diminishing effect on police strength. The size of the police department grows along with the size of the Black population but once their representation reaches about $10 \%$ of the overall city population, police strength levels off then slowly declines. This is consistent with a political version of the threat hypothesis advanced by Jackson (1989) who argues that with a sizable presence, African Americans gain political influence and with such clout appear to be able to reduce discriminatory crime control tactics they perceive as largely directed at members of their own group.

Similarly, our findings indicate that police strength increases as the size of the Hispanic population grows. Unlike our results for African Americans, though, it appears that metropolitan police departments grow at an increasing rate as the Hispanic population expands. This is consistent with traditional threat explanations which suggest that minority presence increases majority group fears. It is not clear, though, why police strength does not decline as the Hispanic population increases. Perhaps Hispanics have not been able to successfully translate their growing numbers into political influence in the same ways that African Americans have. In any case, future research will have to examine this relationship further as the Hispanic population expands further in cities across the United States. 
Finally, our findings provided strong support for an economic version of the threat hypothesis. Despite the well-established connection between income inequality and the use of social control (e.g. Jacobs \& Helms, 2001; Arvanites \& Asher, 1998), most studies looking at police strength have ignored this relationship. Our results show that income inequality is one of the strongest determinants of variation in police strength across U.S. cities in the last several decades. Those cities where economic inequality is high have the most police officers. Future studies would be ill-advised to ignore this factor.

\section{Wider Implications}

Theorists have long argued that racial residential segregation is one of the most persistent and consequential elements of racial inequality in the United States (Quilian \& Pager, 2001; Peterson \& Krivo, 1993, Massey \& Denton, 1987). It has been associated with numerous social problems including joblessness (Wilson 1978), poverty (Krivo, Peterson, Rizzo \& Reynolds, 1998), and levels of crime (Peterson \& Krivo, 1993). Beyond these social ills, theorists have also pointed to the connection between social control and segregation. In particular, both Spitzer (1975) and Blauner (1972) argued that at its highest levels, residential segregation acts as a means of social control that reduces the need for alternative measures such as police protection. Scholars suggest that the residential segregation of racial or ethnic minorities reduces interethnic contact and therefore the likelihood of interethnic victimization (South \& Felson, 1990; Messner \& South, 1986; Blau, 1977). Declines in real or perceived threats from minorities may then reduce perceptions of a crime problem and the demands for aggressive crime control efforts that go with such fears.

The contact hypothesis develops our understanding of the association between levels of segregation and the use of formal social control by suggesting that interethnic contact can reduce negative stereotypes and their potential consequences (Sigelman \& Welch, 1993). Williams (1964) argued that intimate and consistent contact such as that which takes place between neighbors is particularly successful at reducing racial animosities. If majority group members are less afraid of victimization from minorities it stands to reason that they will be less likely to demand aggressive social control measures. Our findings support such a claim. The most racially integrated cities have the smallest police departments after controlling for numerous other factors such as differences in crime rates. Yet, consistent with traditional explanations, police strength increases as segregation increases. In the most segregated cities, though, the size of the municipal police department levels off then declines. This drop-off is consistent with claims by Spitzer (1975) and Blauner (1972) that at high level, racial isolation acts as a form of social control.

Beyond residential segregation, it appears that racial and ethnic composition of a city has a direct effect on the size of local police departments. This is consistent with numerous theoretical claims that the size of the minority population is related to majority group fears and that these fears will translate into greater demands for more aggressive crime control measures (Blalock, 1972). There has been a substantial increase in both the African American and Hispanic populations across the United States since 1980. It appears that this growth has influenced the decision-making of local politicians when they consider the need for police officers. 
Theoretical claims that economic concentration produces an unstable condition that must be maintained by force are also supported here (Chambliss \& Seidman, 1980). Cities with large economic differences between the affluent and the poor have substantially larger police departments. This is consistent with the idea that social control efforts such as police protection are principally a tool used to protect and sustain current social arrangements that benefit the affluent (Collins, 1975; Lenski, 1966). To reiterate, it is important to see both the racial and economic threat findings as part of a larger political process since successful demands for increases in social control must be directed at public officials who can manipulate law enforcement presence. Thus, the threat of a large minority population or the threat of a large underclass must generate pressure on local politicians to increase levels of social control.

Together, our results suggest that, despite claims to the contrary (Wilson, 1978), racial inequality continues to play a strong role in determining the magnitude of crime-control measures across the United States. Despite conventional expectations, differences in population and crime that exist between cities are not the primary drivers of variation in the size of municipal police departments. Rather, our results support neo-Marxist claims that crime control is best seen as an instrument in the struggle between dominant and subordinate group members (Garland, 1990; Quinney, 1974; Turk, 1969). But our results also point to strategies that may eliminate or reduce this struggle. As discussed above, the most integrated communities have the fewest officers on the street presumably because dominant group members hold less prejudicial attitudes towards racial and ethnic minorities in these cities. Thus, policies aimed at reducing racial and ethnic isolation in urban cities should reduce police strength across the United States.

\section{References}

Allport, G. W. (1954). The nature of prejudice. Boston, MA: Addison-Wesley.

Arvanites, T. M., \& Asher, M. A. (1998). State and county incarceration rates: The direct and indirect effects of race and inequality. American Journal of Economics and Sociology, 57, 207-222.

Blalock, H. (1967). Towards a theory of minority group relations. New York: Capricorn Books.

Blau, P. R. (1977). A macrosociological theory of social structure. The American Journal of Sociology, 83, 26-54.

Blauner, R. (1972). Marxian theory and race relations. American Sociological Association Annual Meeting. Bordua, D. J., \& Haurek, E. W. (1971). The Police Budget's Lot: Components of the increases in Local Police Expenditures. In Hahn, H. (Ed.), Police in Urban Society (pp. 57-70). Beverly Hills, CA: Sage Publications.

Carmichael, J. T. (2005). The determinants of jail use across large US cities: An assessment of racial, ethnic, and economic threat explanations. Social Science Research, 34(3), 538-548.

Chambliss, W. J. (1976). Functional and conflict theories of crime. In W. J. Chambliss \& M. Mankoff (Eds.), Whose law? What order? (pp. 1-28). New York: John Wiley.

Chambliss, W. J., \& Seidman, R. (1980). Law, order, and power. Reading: Addison-Wesley.

Chiricos, T. G., \& Delone, M. A. (1992). Labor surplus and punishment: A review and assessment of theory and evidence. Social Problems, 39, 421-446.

Cohen, S., Barkan, S., \& Halterman, W. (1991). Punitive attitudes toward criminals: Racial consensus or racial conflict? Social Problems, 38, 287-296.

Collins, R. (1975). Conflict sociology. Waltham, MA: Academic Press.

DeFina, R., \& Hannon, L. (2009). Diversity, racial threat, and metropolitan housing segregation. Social Forces, 88(1). 
Dyer, J., Vedlitz, A., \& Worchel, S. (1989). The correlates of social distance among social and ethnic groups in Texas. Social Science Quarterly, 70, 607-616.

Ellison, C. G., \& Powers, D. A. (1994). The Contact Hypothesis and Racial Attitudes Among Black Americans. Social Science Quarterly, 75, 385-400.

Garland, D. (1990). Punishment and modern society. Chicago: University of Chicago Press.

Greenberg D. F., \& West, V. (2006). State prison populations and their growth, 1971-1991. Criminology, 39, 615-654.

Greene, W. H., (2012). Econometric analysis. 7th Edition. Upper Saddle River, NJ: Prentice Hall.

Gurr, T. R. (1979). On the history of violent crime in Europe and America. In H. D. Graham \& T. R. Gurr (Eds.), Violence in America: Historical and comparative perspectives (pp. 544-596). Beverly Hills: Sage Publications.

Hahn, H. (1971). Police in Urban Society. Beverly Hills, CA: Sage Publications.

Holmes, M. D., Smith, B. W., Freng, A. B., \& Munoz, E. A. (2008). Minority threat, crime control, and police resource allocation in the Southwestern United States. Crime and Delinquency, 54, 128-152.

Hum, T., \& Zonta, M. (2000). Residential patterns of Asian Americans. In P. Ong (Ed.), The State of Asian Pacific America: Transforming race relations. Los Angeles: LEAP Asian Pacific American Public Policy Institute and UCLA Asian American Studies Center.

Jackson, P. I. (1989). Minority group threat, crime and policing. New York: Praeger.

Jackson, P. I., \& Carroll, L. G. (1981). Race and the war on crime: the sociopolitical determinants of municipal police expenditures. American Sociological Review, 46, 290-305.

Jacobs, D. (1979). Inequality and police strength: conflict theory and coercive control in metropolitan areas. American Sociological Review, 44, 913-925.

Jacobs, D., \& Carmichael, J. T. (2001). The politics of punishment across time and space: A pooled time series analysis of imprisonment rates. Social Forces, 80, 61-89.

Jacobs, D., \& Helms, R. (1997). Testing coercive explanations for order: The determinants of law enforcement strength over time. Social Forces, 75, 1361-1392.

Jacobs, D., \& Helms, R. (2001). Towards a political sociology of punishment: politics and changes in the incarcerated population. Social Science Quarterly, 30, 171-194.

Johnston, J., \& DiNardo, J. (1997). Econometric methods. New York: McGraw Hill.

Kelly, M. (2000). Inequality and crime. The Review of Economics and Statistics, 82, 530-539.

Kent, S. L., \& Jacobs, D. (2005). Minority threat and police strength from 1980 to 2000: A fixed-effects analysis of nonlinear and interactive effects in large cities. Criminology, 43, $731-760$.

Krivo, L. J., Peterson, R. D., Rizzo, H., \& Reynolds, J. (1998). Race, segregation, and the concentration of disadvantage: 1980-1990. Social Problems, 45, 61-80.

Land, K. C., McCall, P. L., \& Cohen, L. E. (1990). Structural covariates of homicide rates: are there any invariances across time and social space? The American Journal of Sociology, 95, 922-963.

Lenski, G. (1966). Power and privilege. New York: Macmillan.

Liska, A. E., \& Chamlin, M. B. (1984). Social structure and crime control among macrosocial units. American Journal of Sociology, 90, 383-395.

Liska, A. E., Lawrence, J. J., \& Benson, M. (1981). Perspectives on the legal order. American Journal of Sociology, 87, 412-426.

Liska, A. E., Lawrence, J. J., \& Sanchirico, A. (1982). Fear of crime as a social fact. Social Forces, 60, 760-771.

Loftin, C., \& McDowall, D. (1982). The police, crime and economic theory. American Sociological Review, 47, 633-644.

Maguire, E. R. (2001). Research evidence on the factors influencing police strength in the United States. In C. S. Koper, E. R. Maguire, \& G. E. Moore (Eds.), Hiring and retention issues in police agencies: Readings on the determinants of police strength, hiring and retention of officers and the federal cops program (pp. 7-25). A report to the National Institute of Justice. Retrieved from http://www.urban.org/ pdfs/Hiring-and-Retention.pdf.

Massey, D. \& Denton, N. (1987). Trends in the Residential Segregation of Blacks, Hispanics, and Asians: 1970-1980. American Sociological Review 52, 802-25.

Massey, D., \& Denton, N. (1989). Hyper Segregation in U.S. Metropolitan Areas: Black and Hispanic Segregation along Five Dimensions. Demography, 26, 373-91.

McCarty, W. P., Ren, L., \& Zhao, J. (2012). Determinants of police strength in large U.S. cities during the 1990s: A fixed-effects panel analysis. Crime and Delinquency, 58, 397-424.

McFarland, M., \& Smith, C. A. (2011). Segregation, race, and infant well-being. Population Research Policy Review, 30, 467-493. 
Messner, S., \& South, S. (1986). Economic deprivation, opportunity structure, and robbery victimization: Intra and interracial patterns. Social Forces, 64, 975-991.

Messner, S. F., \& Golden, R. M. (1992). Racial-inequality and racially disaggregated homicide rates: An assessment of alternative theoretical explanations. Criminology, 30, 421-447.

Myer, A. J., \& Chamlin, M. B. (2011). Aggregation bias and the benign neglect hypothesis. Journal of Crime and Justice, 34(2), 124-138.

Nalla, M. K., Lynch, M. J., \& Leiber, M. J. (1997). Determinants of police growth in Phoenix, 1950-1988. Justice Quarterly, 14, 115-142.

Oliver, \& Mendelberg. (2000). Reconsidering the environmental determinants of white racial attitudes. American Journal of Political Science, 44(3), 574-589.

Ousey, G. C., \& Lee, M. R. (2008). Racial disparity in formal social control: An investigation of alternative explanations of arrest rate inequality. Journal of Research in Crime and Delinquency, 45(3), 322-355.

Peterson, R., \& Krivo, L. J. (1993). Racial segregation and black urban homicide. Social Forces, 71, 10011026.

Pratt, T. C., \& Cullen, F. T. (2005). Assessing macro-level predictors of crime: a meta-analysis. Crime and Justice, 32, 373-450.

Quillian, L., \& Pager, D. (2001). Black neighbors, higher crime? The role of racial stereotypes. The American Journal of Sociology, 107, 717-767.

Quinney, R. (1974). Critique of the legal order. Boston: Little, Brown.

Rubenstein, J. (1973). City police. New York: Farrar, Straus and Giroux.

Rugh, J. S., \& Massey, D. S. (2010). Racial segregation and the American foreclosure crisis. American Sociological Review, 75(5), 629-651.

Rusche, G., \& Kirchheimer, O. (1939). Punishment and social structure. New York: Russell and Russell.

Sever, B. (2001). The relationship between minority populations and police force strength: Expanding our knowledge. Police Quarterly, 4, 28-68.

Sharp, E. B. (2006). Policing Urban America: A new look at the politics of agency size. Social Science Quarterly, 87, 291-307.

Sigelman, L., \& Welch, S. (1993). The contact hypothesis revisited: black-white interaction and positive racial attitudes. Social Forces, 73, 781-795.

South, S., Crowder, K., \& Pais, J. (2011). Metropolitan structure and neighborhood attainment: Exploring intermetropolitan variation in racial residential segregation. Demography, 48(4), 1263-1292.

South, S. J., \& Felson, R. B. (1990). The racial patterning of rape. Social Forces, 69, 71-93.

Spitzer, S. (1975). Toward a marxian theory of deviance. Social Problems, 22, 638-651.

Stucky, T. D. (2005). Local politics and police strength. Justice Quarterly, 22, 139-169.

Stults, B. J., \& Baumer, E. P. (2007). Racial context and police force size: Evaluating the empirical validity of the minority threat perspective. The American Journal of Sociology, 113(2), 507546.

Sutton, J. (2000). Imprisonment and social classification in five common-law democracies, 1955-1985. The American Journal of Sociology, 106, 350-386.

Tittle, C., \& Curran, D. (1988). Contingencies for dispositional disparities in juvenile justice. Social Forces, $67,23-58$.

Turk, A. T. (1969). Criminality and the legal order. Chicago: Rand McNally.

Wacquant, L. (2001) Deadly symbiosis: When ghetto and prison meet and mesh. Punishment \& Society, 3(1), 95-133.

Welch, S., Sigelman, L., Bledsoe, T., \& Combs, M. (2001). Race and place: Race relations in an American city. New York: Cambridge University Press.

White, H. (1980). A heteroskedasticity-consistent covariance matrix estimator and a direct test for heteroskedasticity. Econometrica 48(4), 817-838.

Williams, R. M. Jr. (1964). Strangers Next Door: Ethnic Relations in American Communities. Engle-wood Cliffs, N.J.: Prentice-Hall.

Wilson, J. Q. (1971). Varieties of police behavior. New York: Atheneum.

Wilson, W. J. (1978). The declining significance of race: blacks and changing American Institutions. Chicago: University of Chicago Press.

Zhao, J., Ren, L., \& Lovrich, N. (2012). Political culture vs. socioeconomic approaches to predicting police strength in U.S. police agencies: Results of a longitudinal study, 1993-2003. Crime \& Delinquency, 58(2), 167-195. 